\title{
THREATENED SAN CLEMENTE BELLSS SPARROW NEST DEPREDATED BY ISLAND NIGHT LIZARD
}

\author{
Andrew S. Bridges 1,2 , Daniel S. Biteman ${ }^{1}$, \\ Emma E. Deleon ${ }^{1}$, and Brian E. Cross ${ }^{1}$
}

\begin{abstract}
We used remote video monitoring systems to document nest predators at San Clemente Bell's Sparrow (Artemisiospiza belli clementeae) nests and recorded an unexpected depredation by an island night lizard (Xantusia riversiana) on 22 May 2013. This record is the first documented case of a San Clemente Bell's Sparrow being depredated by any reptile and is also the first documentation of any night lizard species (genus Xantusia) depredating a bird's nest. Additionally, we found that night lizards are among the smallest lizard species ever observed depredating a bird's nest.

Resumen.-Utilizamos sistemas de monitoreo remoto con vídeo para documentar depredadores de nidos de gorriones en San Clemente Bell (Artemisiospiza belli clementeae) y grabamos una depredación inesperada por un lagartija nocturna de la isla (Xantusia riversiana) el 22 de mayo del 2013. Este registro es el primer caso documentado de un gorrión de San Clemente Bell siendo depredado por un reptil y es también la primera documentación de una lagartija nocturna (género Xantusia) depredando un nido de ave. Además, encontramos que las lagartijas nocturnas se encuentran entre las lagartijas más pequeñas observadas depredando un nido de aves.
\end{abstract}

The San Clemente Bell's Sparrow (Artemisiospiza belli clementeae; hereafter, Bell's Sparrow) is a nonmigratory subspecies endemic to San Clemente Island, California. The subspecies (previously known as the San Clemente Sage Sparrow) is currently listed as threatened by the U.S. Fish and Wildlife Service (USFWS) under the Endangered Species Act (ESA; USFWS 1977).

The island night lizard (Xantusia riversiana) is endemic to 3 of the California Channel Islands (San Clemente, San Nicolas, and Santa Barbara). It was listed as threatened under the ESA (USFWS 1977) but was recently delisted following a population estimate of $>20,000,000$ (USFWS 2014). Island night lizards are omnivorous, with an eclectic diet consisting largely of arthropods, vegetation, and rarely, neonatal deer mice (Peromyscus maniculatus; Knowlton 1949, Fellers and Drost 1991).

The southernmost of the California Channel Islands, San Clemente Island $\left(118^{\circ} 30^{\prime} \mathrm{W}\right.$, $33^{\circ} 00^{\prime} \mathrm{N}$ ) is owned by the U.S. Navy (USN) and is located $125 \mathrm{~km}$ west of San Diego, California (USN 2013). It is approximately $145 \mathrm{~km}^{2}$ and experiences a Mediterranean climate with dry summers and winter rains. The predominant vegetative communities include maritime desert scrub, canyon woodlands, and grasslands.
We monitored nests using small video cameras connected remotely to digital video recorders with 12-volt-battery power supplies.

The Bell's Sparrow nest where the predation occurred was located on 24 April 2013, and a nest monitoring system was installed on 11 May 2013. The nest was constructed in boxthorn (Lycium californicum) and was built $17 \mathrm{~cm}$ above ground level. Within a 30-m radius of the nest, ground cover consisted of approximately 35\% mixed grass (Nasella and Stipa spp.), $25 \%$ boxthorn, $15 \%$ prickly pear cactus (Opuntia littoralis), 15\% bare ground, $5 \%$ mixed cactus species, and 5\% mixed herbaceous vegetation.

The nest contained 3 eggs which hatched on 17 May 2013. On 22 May 2013, an island night lizard depredated (dragged from the nest) one of the 5-day-old chicks and caused the other 2 chicks to leave the nest prematurely. Nestlings typically fledge approximately 12 days after hatching, so it is unlikely the premature fledglings survived. Subsequent visual observation of the nest and surrounding area by Institute for Wildlife Studies (IWS) ornithologists failed to document the parents carrying food to potential fledgling hiding spots in the surrounding vegetation, further suggesting the fledglings did not survive.

\footnotetext{
${ }^{1}$ Institute for Wildlife Studies, 2327 Kettner Blvd. San Diego, CA 92101
}

2E-mail: bridges@iws.org 
Neither of the adult Bell's Sparrows was present immediately prior to, or during, the depredation event. The night lizard first appeared on camera at 15:58 and within $1 \mathrm{~min}$ it seized a nestling and dragged it to the rim of the nest cup where the nestling thrashed free from the lizard's grasp and returned to its nestmates. The lizard then disappeared from view for approximately 5 min before returning at 16:04. As the lizard approached the nestlings at 16:05, one of the nestlings jumped out of the nest. The lizard then seized one of the 2 remaining nestlings and lifted it into the air before dragging it over the rim of the nest and out of view. After the lizard's departure with its nestmate, the third and final nestling jumped from the nest at 16:06.

We estimated the size of the night lizard based on the size of the nest and published morphological descriptions. The night lizard appeared to be an adult between 60 and 90 $\mathrm{mm}$ in snout-vent length, which corresponds to an approximate weight of 15-25 g (Goldberg and Bezy 1974, Fellers and Drost 1991). At 5 days post-hatching, Bell's Sparrow nestlings weigh approximately 10-12 g (IWS unpublished data).

Larger lizards (>300 g) are often energetically compelled to rely on vertebrate prey (Pough 1973), and bird nest contents are particularly important to the varanids (Losos and Greene 1988) and helodermatids (Beck 1990). Nest contents also have been documented in the diets of alligator lizards (Elgaria spp.; Cunningham 1956) and ocellated lizards (Lacertida lepida; Castilla et al. 1991). In our review of the literature, the Madeiran wall lizard (Teira dugesii) was the only similarly sized $(\leq 80 \mathrm{~mm}$; Arnold et al. 2007) lacertilian documented depredating bird nests (Matias et al. 2009).

Night lizards exist at high densities on San Clemente Island's marine terraces and boxthorn habitat (Fellers and Drost 1991), which is also the primary breeding habitat of the Bell's Sparrow (Kaiser et al. 2009). However, despite the sympatry of Bell's Sparrow and the island night lizard, our video evidence suggests that depredation by night lizards is relatively rare and unlikely to pose a substantive threat to Bell's sparrow population viability.

This research was funded by the USN, Commander Pacific Fleet. We thank the 2013 Bell's Sparrow Monitoring and the Predator
Research Ecology and Management teams for conducting this project. We thank Melissa Booker, Jacqueline Rice, and David Garcelon for their project oversight and review of this paper. We thank Scott Sillet and one anonymous reviewer for their comments and suggestions for improving this manuscript. We thank Sandy Vissman of the USFWS for her assistance and support of this project.

\section{Literature Cited}

Arnold, N.E., O. Arribas, and S. Carranza. 2007. Systematics of the palaearctic and oriental lizard tribe Lacertini (Squamata: Lacertidae: Lacertinae), with descriptions of eight new genera. Zootaxa 1430:1-86.

BECK, D.D. 1990. Ecology and behavior of the gila monster in southwestern Utah. Journal of Herpetology 24:54-68.

Castilla, A.M., D. Bauwens, and G.A. Llorente. 1991. Diet composition of the lizard Lacerta lepida in central Spain. Journal of Herpetology 25:30-36.

Cunningham, J.D. 1956. Food habits of the San Diego alligator lizard. Herpetologica 12:225-230.

Fellers, G.M., AND C.A. Drost. 1991. Ecology of the island night lizard, Xantusia riversiana, on Santa Barbara Island, California. Herpetological Monographs 5:28-78.

GoldberG, S.R., AND R.L. BEZY. 1974. Reproduction in the island night lizard, Xantusia riversiana. Herpetologica 30:350-360.

Kaiser, S.A., E.L. Kershner, and D.K. Garcelon. 2009. Proceedings of the 7th California Islands Symposium. Institute for Wildlife Studies, Arcata, CA.

Knowlton, G.F. 1949. Food of the island night lizard. Herpetologica 5:45-46.

Losos, J.B., AND H.W. GReEnE. 1988. Ecological and evolutionary implications of diet in monitor lizards. Biological Journal of the Linnean Society 35:379-407.

Matias, R., R. Rebelo, J.P. Granadeiro, and P. Catry. 2009. Predation by Madeiran wall lizards Teira dugesii on Cory's Shearwater Calonectris diomedea hatchlings at Selvagem Grande, North Atlantic. Waterbirds 32:600-603.

Pough, F.H. 1973. Lizard energetics and diet. Ecology 54:837-844

[USN] Unites States NAVy. 2013. Integrated Natural Resources Management Plan Naval Auxiliary Landing Field San Clemente Island, California. Prepared for Naval Base Coronado and Naval Facilities Engineering Command Southwest by Tierra Data Inc., Escondido, California. Federal Register 42:4068240685.

[USFWS] United States Fish AND Wildlife SERVICE. 1977. Endangered and threatened wildlife and plants. Federal Register 42:40682-40685.

2014. Endangered and Threatened Wildlife and Plants; Removing the island night lizard from the federal list of endangered and threatened wildlife. Federal Register 79:18190-18210.

Received 12 November 2014 Accepted 11 February 2015 